\title{
Deficiency of an enzyme of tyrosine metabolism underlies altered gene expression in newborn liver of lethal albino mice
}

\author{
Siegfried Ruppert, ${ }^{1,2}$ Gavin Kelsey, ${ }^{2}$ Andreas Schedl, Erika Schmid, Edda Thies, \\ and Günther Schütz ${ }^{3}$ \\ Institute of Cell and Tumor Biology, German Cancer Research Center, W-6900 Heidelberg, Germany
}

\begin{abstract}
Mice homozygous for albino deletions encompassing the locus alf/hsdr-1 die shortly after birth. Lethality is thought to be the consequence of hypoglycemia, which results from the failure to activate hormone-dependent genes in liver and kidney encoding enzymes important for gluconeogenesis. Within the region in which alf/hsdr-1 has been defined by physical mapping, we identified the gene encoding fumarylacetoacetate hydrolase (FAH), an enzyme of tyrosine metabolism. Lack of FAH activity should lead to accumulation of toxic tyrosine metabolites. In man, genetically determined FAH deficiency is the primary defect in tyrosinemia type I, a fatal liver disease of infants. Northern blot and in situ hybridization analysis of mouse tissues showed that the cell types that normally express FAH correspond to those that exhibit a phenotype in alf/hsdr-1 deletion mice. Moreover, we could mimic aspects of the alf/hsdr-1 deletion phenotype in vitro by treating primary hepatocyte cultures with an intermediate of tyrosine metabolism. These findings strongly suggest that alf/hsdr-1 encodes FAH and that absence of FAH is responsible for neonatal lethality in albino deletion mice. Mechanisms by which this metabolic defect might bring about alterations in gene expression characteristic of the alf/hsdr-1 deletion phenotype are discussed.
\end{abstract}

[Key Words: alf/hsdr-1; albino-deletion complex; fumarylacetoacetate hydrolase; liver-specific gene expression; hormone inducibility; tyrosinemia type I]

Received April 13, 1992; revised version accepted June 8, 1992.

Mutations that affect the differentiation of specific cell types in higher eukaryotes have enormous potential for identifying factors that contribute to cell type-specific gene expression. One such genetic resource in the mouse is the albino-deletion complex on chromosome 7 , which comprises at least 37 radiation-induced chromosomal deletions overlapping at the albino locus, $c$. The deletions have been organized into 13 complementation groups, which define several loci essential for normal development before or after birth (Russell et al. 1982; for review, see Rinchik and Russell 1990). One locus is necessary for survival beyond birth and has been proposed to play an important role in the perinatal differentiation of the hepatocyte (Gluecksohn-Waelsch 1979). The locus is designated alf [factor indicated by the albino lethal mutation (Ruppert et al. 1990)| or hsdr-1 [hepatocyte-specific developmental regulation-1 (McKnight et al. 1989) and is referred to as alf/hsdr-1 in this paper.

\footnotetext{
'Present address: Howard Hughes Medical Institute, Department of Molecular and Cell Biology, University of California at Berkeley, Berkeley, California 94720 USA.

${ }^{2}$ These authors contributed equally to this work.

${ }^{3}$ Corresponding author.
}

Mice homozygous for albino deletions that include alf/hsdr-1 die several hours after birth. Lethality is associated with severe hypoglycemia, and the failure to activate several enzymes in liver involved in gluconeogenesis, notably glucose-6-phosphatase, tyrosine aminotransferase (TAT), and phosphoenolpyruvate carboxykinase (PEPCK) (Erickson et al. 1968; Thorndike et al. 1973; Schmid et al. 1985; Loose et al. 1986). Many other enzymes and proteins are present at normal levels (Gluecksohn-Waelsch 1979; Baier et al. 1984). Decreased transcription has been shown to be responsible for these and other enzyme deficiencies (Loose et al. 1986; Morris et al. 1988; Ruppert et al. 1990). Analysis of a representative set of affected mRNAs identified by subtractive cDNA hybridization suggested that expression of the affected genes was normally inducible by glucocorticoids and/or cAMP around birth in liver (Ruppert et al. 1990). In contrast, expression of glucose-6-phosphatase, TAT, and the metallothionein $\mathrm{Mt}-1$ gene cannot be induced by exogenous hormones in mutant liver (Thorndike et al. 1973; Schmid et al. 1985; DeFranco et al. 1988). These observations were compatible with a hypothesis that alf/ $h s d r-1$ encodes a regulatory factor essential for cell type- 
specific and hormone-dependent gene expression (Gluecksohn-Waelsch 1987; Ruppert et al. 1990). A specific deficit of factors in the signal transduction pathways for glucocorticoid and cAMP has not been found, however (Ruppert et al. 1990; DeFranco et al. 1991). In contrast, the mRNAs for some transcription factors enriched in liver, C/EBP, HNF-1, and HNF-4, are present at reduced levels (McKnight et al. 1989; Gonzalez et al. 1990; Ruppert et al. 1990; Tönjes et al. 1992).

The reduced expression of specific mRNAs in the affected mice is limited to two cell types: the parenchymal cells of the liver, and proximal convoluted tubule cells in the kidney (Ruppert et al. 1990). Analysis by electron microscopy has revealed that extensive ultrastructural abnormalities are present in the same two cell types in late fetal and newborn mutant mice (Trigg and Gluecksohn-Waelsch 1973).

Whereas much interest has focused on decreased expression of liver-specific genes, some mRNAs show increased abundance in livers of mice homozygous for neonatally lethal albino deletions. These include the mRNA for $\mathrm{NAD}(\mathrm{P} \mid \mathrm{H}$ : menadione oxidoreductase (NMO-1), an enzyme involved in oxidative detoxification (Petersen et al. 1989), and three mRNAs induced by growth arrest and DNA damage, so-called gadd transcripts (Fornace et al. 1989). This adds to earlier findings of increased UDPglucoronyltransferase and glutathione $S$-transferase B (GST) activities (Thaler et al. 1976; Gatmaitan et al. 1977), two enzymes which, like NMO-1, belong to the aryl hydrocarbon $(A h)$ battery (Nebert et al. 1990). A locus encoding a negative regulator of members of the $A h$ battery, designated Nmo-1n, has been proposed from these observations (Nebert et al. 1990).

Because of the pleiotropic phenotype associated with neonatally lethal albino deletions, the function of the alf/hsdr-1 gene product has been difficult to predict. Therefore, we sought to isolate alf/hsdr-1 by "positional cloning." We established a physical map of the region of chromosome 7 corresponding to the albino-deletion complex including the $\sim 3800 \mathrm{~kb}$ absent in the "prototypic deletion" $c^{14 C o S}$ (Kelsey et al. 1992). From markers closely flanking alf/hsdr-1, chromosome jumping libraries were then used to isolate new markers mapping between the proximal breakpoints of the deletions $c^{10 R 75 M}$ and $c^{11 D S D}$, the deletions that bracket alf/hsdr-1 (Schedl et al. 1992). The identification of these two breakpoints allowed us to limit alf/hsdr-1 to $\sim 310 \mathrm{~kb}$, and more than one-third of this region has now been cloned by walking in $\lambda$ and cosmid libraries (Schedl et al. 1992).

We set the following criteria that a candidate gene for alf/hsdr-1 should satisfy: (1) the gene must be entirely or partly absent from $c$-locus deletions that involve alf/ $h s d r-1 ;(2)$ assuming that the gene product acts cell autonomously, the gene must be expressed in hepatocytes and in proximal tubular cells of the kidney; and (3) the gene must normally be expressed at a time preceding or coinciding with the development of the alf/hsdr-1 deletion phenotype.

We identified the gene for fumarylacetoacetate hydrolase $(\mathrm{FAH})$ within the alf/hsdr-1 region. Identification of the Fah gene suggests a novel and unifying explanation for the alf/hsdr-1 deletion phenotype.

\section{Results}

The alf/hsdr-1 deletion phenotype develops before birth in liver and kidney

The altered gene expression in mice homozygous for deletions including alf/hsdr-1 has been analyzed most extensively in newborn liver, and it has been concluded that expression of TAT and PEPCK is affected only after birth (Donner et al. 1988). To determine when a phenotype first arises in mice homozygous for the alf/hsdr-1 deletion $c^{14 C o S}$, we followed the expression of a set of mRNAs in liver before and after birth. The mRNAs included those for TAT, PEPCK, S-adenosylmethionine synthetase (SAMS), mitochondrial 3-hydroxy-3-methylglutaryl-CoA-synthase (CoAS), and an anonymous transcript, X1, whose cDNA was among those identified by differential screening (Ruppert et al. 1990). PEPCK mRNA was not detected before birth, and a decreased abundance in mutant liver is first apparent immediately after birth when PEPCK expression is strongly induced in wild-type mice (Fig. 1). The low levels of TAT and X1 mRNAs present before birth are only slightly reduced, and the failure to attain high levels after birth is the

\begin{tabular}{|c|c|}
\hline Liver & 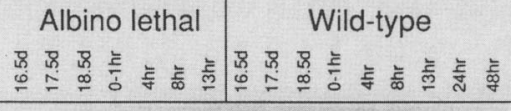 \\
\hline TAT & 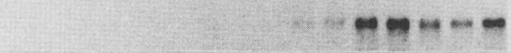 \\
\hline PEPCK & 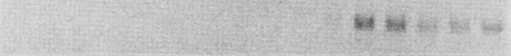 \\
\hline $\mathrm{X} 1$ & acou \\
\hline COAS & 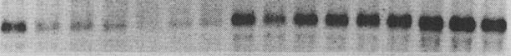 \\
\hline SAMS & 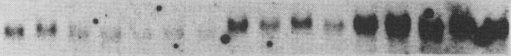 \\
\hline NMO-1 & 1) 4 be this is \\
\hline FOS & 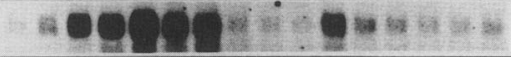 \\
\hline Kidney & 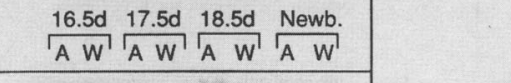 \\
\hline NMO-1 & 84 4 \\
\hline
\end{tabular}

Figure 1. The alf/hsdr-1 deletion phenotype develops before birth in liver and kidney. Total RNA $(10 \mu \mathrm{g})$ from livers of lethal albino mice and wild-type littermates at time points before birth $(16.5,17.5$, and 18.5 days of gestation) and after birth (0-1 to $48 \mathrm{hr}$ ) were analyzed by Northern blot hybridization with the following cDNA probes: TAT, PEPCK, CoAS, SAMS, NMO-1, and FOS $(\mathrm{c}-f o s) . \mathrm{X} 1$ is an unidentified cDNA isolated by differential screening (Ruppert et al. 1990). The cDNAs for CoAS and SAMS correspond, respectively, to cDNAs X5 and X2 isolated by differential screening (Ruppert et al. 1990). (Inset below) A similar analysis for NMO-lmRNA in kidney (5 $\mu \mathrm{g}$ of total RNA) from lethal albino mice $\left[(\mathrm{A}) \mathrm{c}^{14 \mathrm{CoS}} / \mathrm{c}^{14 \mathrm{CoS}}\right]$ and normal littermates [(W) wild type]. (Newb.) Newborn mice $1-4 \mathrm{hr}$ after birth. Each RNA was prepared from organs pooled for each time point. 
greatest effect in mutant liver. SAMS and CoAS mRNAs are readily detectable before birth and are present in similar amounts in mutant and wild-type livers at day 16.5 of gestation. Subsequently, their levels decline in mutant liver, and SAMS fails to exhibit the strong neonatal induction characteristic of wild type. That decreases in the steady-state level of some mRNAs do occur before birth is in agreement with the recent observation of reduced transcription rates for several genes in late fetal $c^{14 C o S} / c^{14 C o S}$ liver (Tönjes et al. 1992).

The mRNA for the detoxifying enzyme NMO-1 is highly induced in $c^{14 \operatorname{Cos}} / c^{14 \operatorname{Cos}}$ liver (Peterson et al. 1989 |. We find that NMO-1 mRNA is present at a high level at day 16.5 both in mutant liver and kidney (Fig. 1).

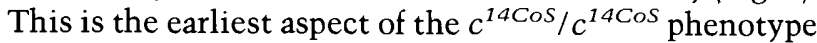
detected. We also examined the expression of FOS mRNA to extend a previous finding of elevated FOS mRNA in newborn liver of mutant mice (Ruppert 1988). The level of FOS mRNA was low in liver of wild-type mice, except for an increase around the first hour after birth. The expression profile in $c^{14 \operatorname{CoS}} / c^{14 \operatorname{CoS}}$ liver differed strikingly in two respects: FOS mRNA was clearly elevated at fetal day 18.5, and a high level was maintained for several hours after birth (Fig. 1).

The alf/hsdr-1 deletion phenotype results from loss of a gene(s) located in $a \sim 315-\mathrm{kb}$ interval

Much of the analysis of the alf/hsdr-1 phenotype has concerned deletion $c^{14 C o S}$ because, apart from removal of the $c$ locus, $a l f / h s d r-1$ is the only function affected. Although it was likely from complementation analysis (Gluecksohn-Waelsch 1979; Russell et al. 1982) that alf/ $h s d r-1$ is defined by the proximal region of the $c^{14 C o s}$ deletion, the possibility remained that separate loci were responsible for each aspect of the $c^{14 C o S}$ deletion phenotype, particularly in light of the finding that the $c^{14 \operatorname{Cos}}$ deletion is $\sim 3800 \mathrm{~kb}$ (Kelsey et al. 1992). The compound heterozygote $c^{11 D S D} / c^{14 C o S}$ is complemented for neonatal lethality and glucose-6-phosphatase deficiency (Russell et al. 1982), and physical mapping indicates that only the most proximal $\sim 315 \mathrm{~kb}$ of the $c^{14 \mathrm{CoS}}$ deletion is restored in the compound heterozygote [(Schedl et al. 1992) shown schematically in Figure 2A]. To examine whether this region was essential for the correct expression of our set of affected genes, the abundance of their mRNAs was compared in newborn livers from $c^{14 C o S} / c^{14 C o S}$ and $c^{11 D S D} / c^{14 C O S}$ mice. Whereas TAT, PEPCK, SAMS, and CoAS mRNAs are severely reduced in $c^{14 \operatorname{CoS}}$ homozygotes, they are present in normal amounts in the $c^{11 D S D /}$ $c^{14 C o s}$ heterozygote (Fig. 2B). In addition, the elevation of NMO-1 mRNA was not seen in $c^{11 D S D} / c^{14 C o S}$ liver. Therefore, all facets of the $c^{14 C o S}$ deletion phenotype so far examined depend on the loss of a gene(s) that maps to the same $\sim 315$-kb interval between the proximal breakpoints of $c^{14 C o S}$ and $c^{11 D S D}$ deletions.

\section{A gene identified within the alf/hsdr-1 region} encodes FAH

Nearly one-third of the region between the proximal
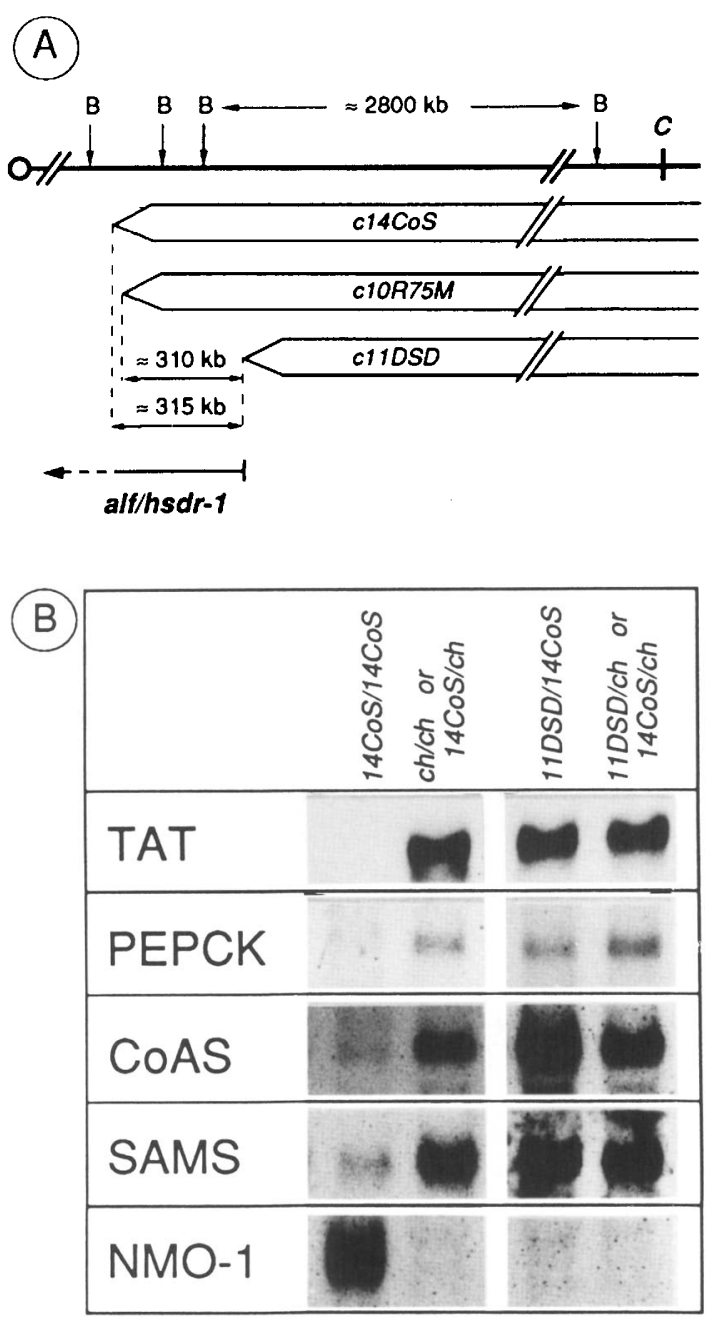

Figure 2. The alf/hsdr-1 deletion phenotype results from the loss of a gene(s) located in a $\sim 315-\mathrm{kb}$ interval. (A) Schematic representation of the location of alf/hsdr-1 on mouse chromosome 7. (Top line) BssHII (B) restriction sites on the wild-type chromosome mapped within the region defined by the albino deletion complex (Kelsey et al. 1992). (c) Albino locus; (O) the centromere. Below, the proximal extensions of the $c^{14 \mathrm{Cos}}$, $c^{1 O R 75 M}$, and $c^{11 D S D}$ deletions are shown by open arrows according to Schedl et al. (1992). All or part of a candidate gene for alf/hsdr-1 maps within the $\sim 315-\mathrm{kb}$ interval between the $c^{11 D S D}$ and $c^{14 C o S}$ deletion breakpoints; the broken arrow indicates the possibility that a candidate gene might extend beyond the proximal extremes of the $c^{10 R 75 M}$ or $c^{14 C O S}$ deletions. The proximal breakpoints of the $c^{10 R 75 M}$ and $c^{14 C O S}$ deletions are separated by $5 \mathrm{~kb}$ (Schedl et al. 1992). alf/hsdr-1 is $\geqslant 3000 \mathrm{~kb}$ from $c$ (Kelsey et al. 1992). (B) Total RNA $(5 \mu \mathrm{g})$ isolated shortly after birth from the livers of lethal albino mice $\left(c^{14 \operatorname{Cos}} / c^{14 C o S}\right)$, and their normal littermates $\left(c^{c h} / c^{c h}\right.$ or $\left.c^{c h} / c^{14 C o s}\right)$, or complemented double heterozygotes $\left(c^{11 D S D} / c^{14 C o S}\right)$ and their normal littermates $\left(c^{11 D S D} / c^{c h}\right.$ or $\left.c^{14 C o S} / c^{c h}\right)$ were analyzed by Northern blot hybridization with the indicated cDNA probes (for abbreviations, see Fig. 1).

boundaries of the $c^{14 C O S}$ and $c^{11 D S D}$ deletions has been isolated as $\lambda$ and cosmid contigs (Schedl et al. 1992). To identify potentially expressed sequences, single-copy probes from each contig were tested for cross-species ho- 
mology by hybridization to "zoo blots" (data not shown). Cloned regions proximal to the $c^{14 C o S}$ deletion were also screened because of the possibility that a candidate gene could extend beyond the proximal extreme of the deletion.

Three probes (RN.Fd, RN.Fa, and JRN2.3 in Fig. 4B, below) in a $10-\mathrm{kb}$ region of a contig designated $\mathrm{RN}$ (for the location of this contig, see Schedl et al. 1992) spanning the proximal end of the $c^{14 \operatorname{CoS}}$ deletion detected cross-hybridization with rat, human, and bovine DNAs (data not shown). In addition, the same probes hybridized on Northern blots to a $\sim 1.6-\mathrm{kb}$ transcript in RNA from newborn livers of wild-type but not $c^{14 C o S} / c^{14 C o S}$ mice (data not shown). These probes were used to screen a newborn liver cDNA library, and 12 cDNA clones were isolated. Four near full-length cDNAs were sequenced completely and found to encode a polypeptide of 419 amino-acid residues with $88 \%$ amino acid sequence identity to human FAH (Fig. 3A), whose cDNA was isolated recently (Agsteribbe et al. 1990; Phaneuf et al. 1991). FAH catalyzes the final reaction in the degradation of tyrosine (Fig. 3B). FAH deficiency in man is the primary defect in the autosomal recessive liver disease tyrosinemia type I (Kvittingen 1986), whose significance for the alf/hsdr-1 deletion phenotype is dealt with in the discussion.

The three genomic fragments that identified the FAH transcript overlap the proximal border of the $c^{14 C o S}$ deletion and are proximal to the $c^{10 R 75 M}$ deletion (Fig. 4B). Because these two $c$-locus deletions have breakpoints that are closest proximally to alf/hsdr-1, we investigated how the Fah gene was altered by the deletions. Homozygous $c^{1 \text { 1OR75M }}$ and $c^{14 C O S}$ DNAs were compared with wild-type control $c^{\text {ch }} / c^{c h}$ and C3H DNAs on Southern blots hybridized with a near full-length Fah cDNA, pmcFAH3 (Fig. 4A). Altered restriction fragments were detected in both deletion DNAs, from which it was concluded that the $c^{14 C o S}$ deletion removes the first two exons of the Fah gene while the $c^{10 R 75 M}$ deletion does not disrupt coding regions, but its proximal breakpoint maps $<1 \mathrm{~kb} 5^{\prime}$ to the start site of transcription [Fig. 4B; the structural characterization of the Fah gene will be presented elsewhere (G. Kelsey, unpubl.)]. FAH mRNA is not detected in newborn liver of $c^{14 C o S}$ homozygotes
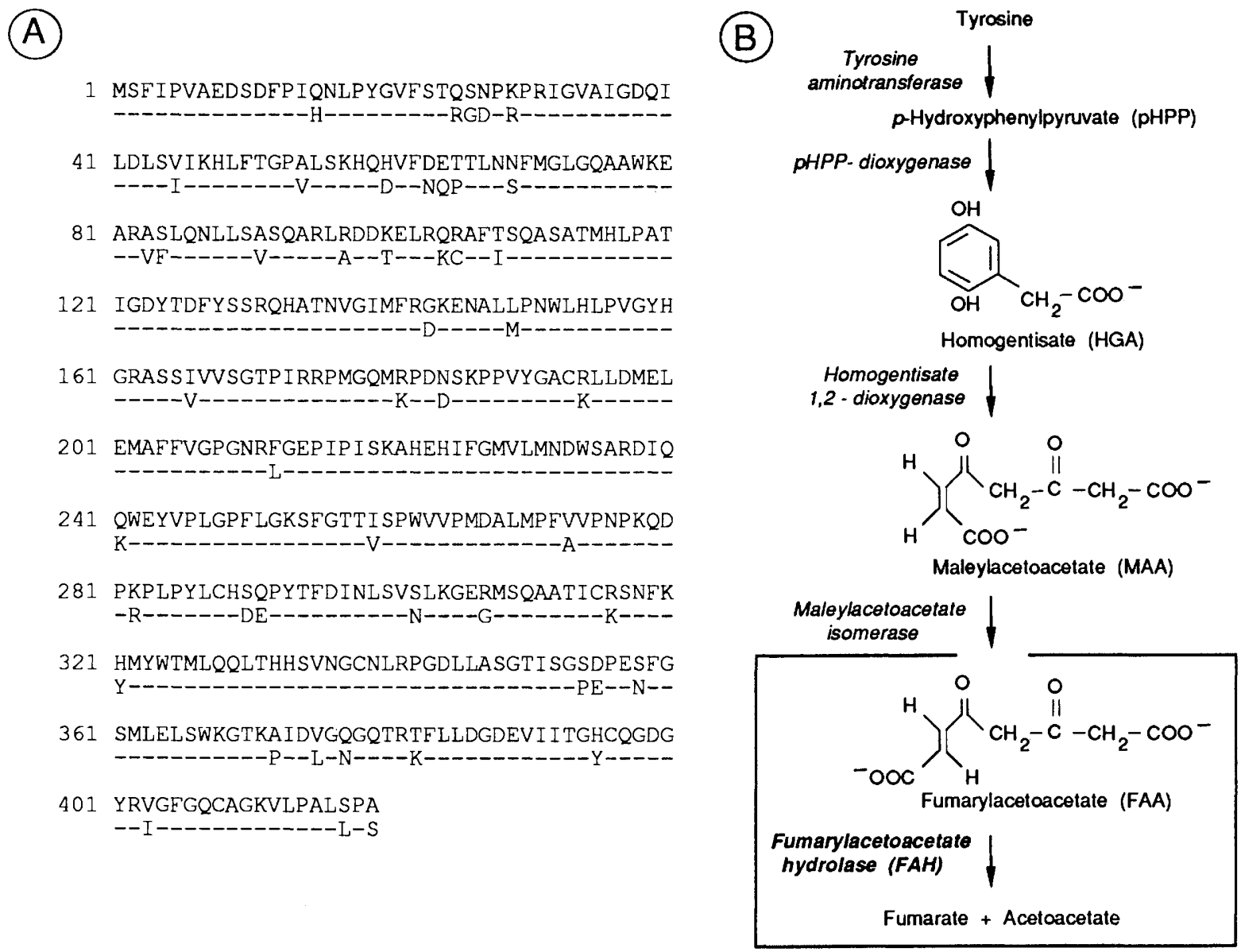

Figure 3. A gene identified within the alf/hsdr-1 region encodes FAH. (A) Amino acid comparison (shown as the single-letter code) of the derived amino acid sequence from the full-length cDNA clone pmcFAH7 with that of human FAH (Agsteribbe et al. 1990; Phaneuf et al. 1991). (Top) The mouse sequence; (bottom) identical amino acid residues between the mouse and human sequences are indicated by a dash in the human sequence. Numbers at left refer to amino acid residues from the presumed initiating methionine. $(B)$ Representation of the tyrosine degradation pathway. The reaction catalyzed by FAH is enclosed within the box. 


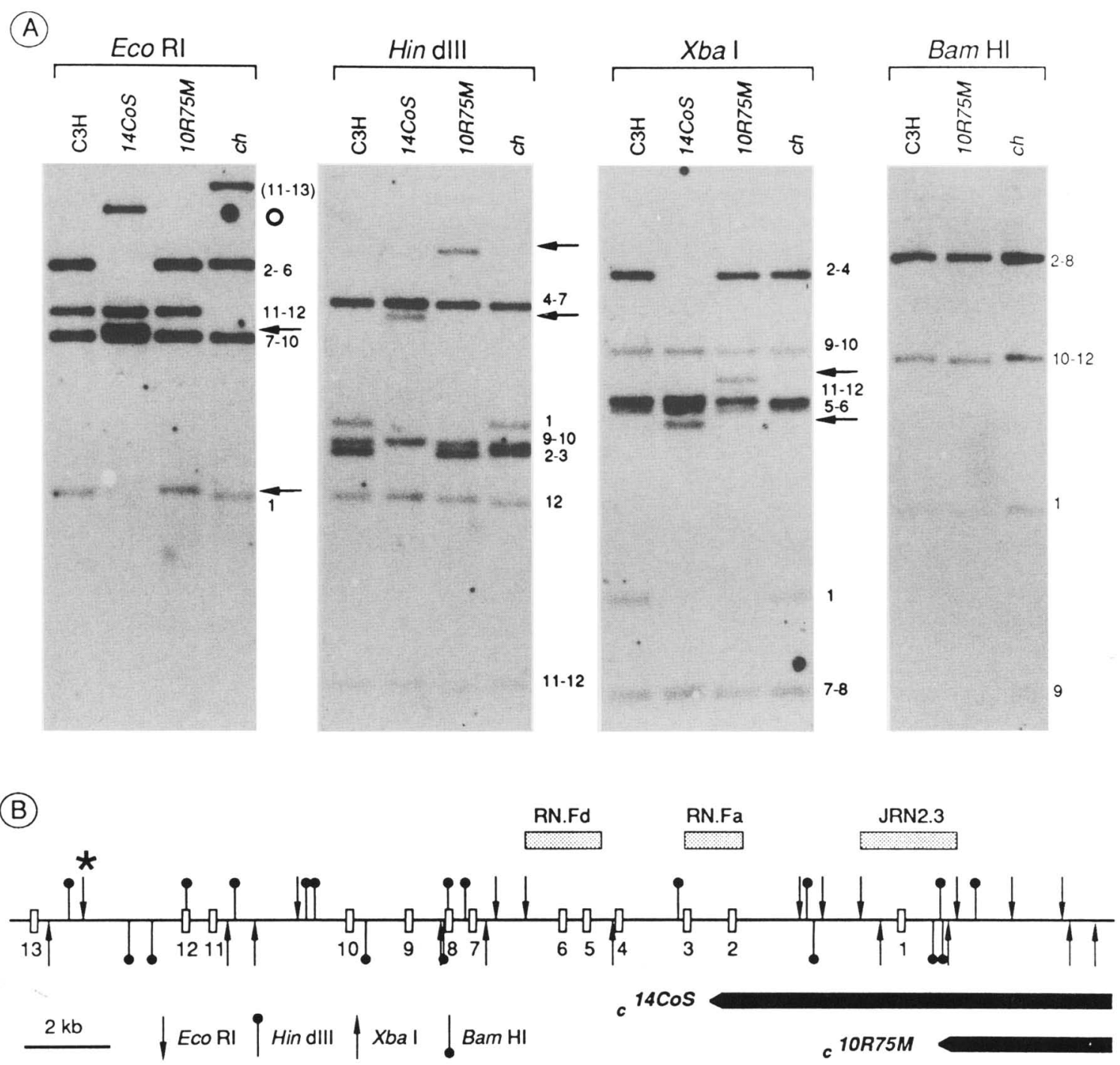

Figure 4. Location of the $c^{14 \operatorname{CoS}}$ and $c^{10 R 75 M}$ deletion breakpoints within the mouse Fah gene. (A) Southern blots of EcoRI, HindIII, $\mathrm{XbaI}$ and $\mathrm{BamHI}$-digested DNAs from mice homozygous for the $c^{14 C o S}$ or $c^{10 R 75 M}$ deletions and control homozygous $c^{c h}$ and $\mathrm{C} 3 \mathrm{H}$ mice were hybridzed with a near full-length FAH cDNA, pmcFAH3. pmcFAH3 lacks sequences corresponding to exon 13 of the Fah gene and was used to avoid detection of exon 13 containing EcoRI and HindIII fragments, which comigrate with other exon fragments (G. Kelsey, unpubl.). The numbers adjacent to the $c h$ lanes refer to the exons present on the indicated restriction fragments. The arrows identify fragments of altered mobility in the two deletion DNAs. An EcoRI site absent on the $c^{c h}$ allele (identified by an asterisk in $B$ ) gives rise to a larger fragment for exons 11-13 [shown as (11-13)]. (O) An EcoRI fragment in the $c^{14 C o S}$ lane suspected to be a partial digestion product. $(B)$ The extents of the $c^{14 C O S}$ and $c^{10 R 75 M}$ deletions are shown as solid arrows below the map of EcoRI, HindIII, XbaI, and BamHI restriction sites of the mouse Fah gene. The $c^{10 R 75 M}$ deletion breakpoint has been mapped between BamHI and HindIII sites within genomic fragment JRN2.3 (Schedl et al. 1992). Exons of the Fah gene are represented by open boxes. Derivation of the exon/intron organization will be presented elsewhere (G. Kelsey, unpubl.). The three single-copy genomic fragments that showed cross-hybridization between mouse, human, and calf DNA and that identified the FAH transcript in liver RNA are indicated by the stippled boxes. The EcoRI site absent on the $c^{c h}$ allele is marked by an asterisk (*).

(Fig. 5B) nor $c^{10 R 75 M}$ homozygotes (Klebig et al. 1992). The failure of the Fah gene to be expressed from the $c^{10 R 75 M}$ chromosome might indicate that the deletion removes sequences essential for expression. Consistent with this notion, we have found that a region underlying a DNase I hypersensitive site in liver and kidney chromatin associated with Fah gene activity is removed by the deletion (G. Kelsey, unpubl.).
The Fah gene is expressed before birth and in cell types that display the alf/hsdr-1 deletion phenotype

The expression of FAH mRNA was investigated to see whether it satisfied expectations for a candidate gene for alf/hsdr-1. The alf/hsdr-1 deletion phenotype is present specifically in liver and kidney. Northern blot analysis of RNAs from adult tissues revealed high-level expression 


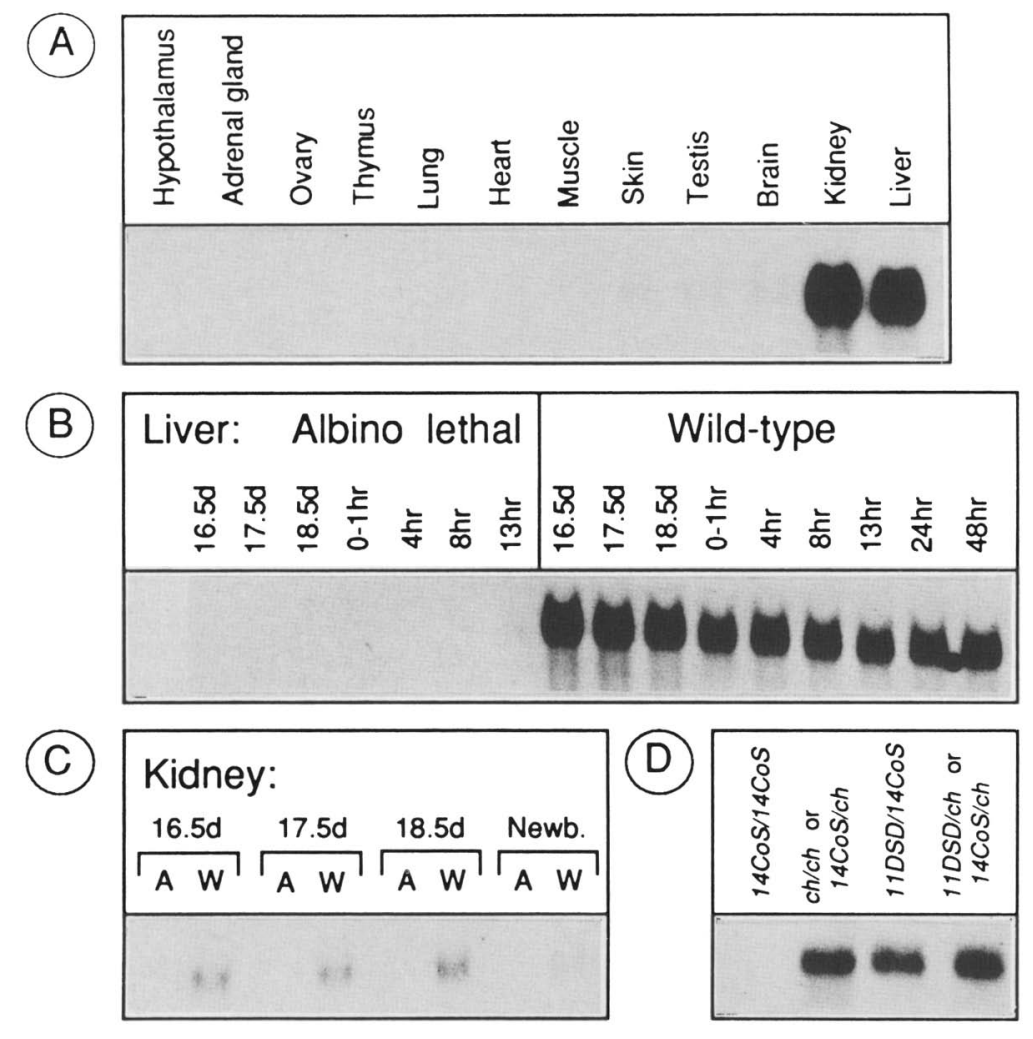

Figure 5. Expression analysis of the $F a h$ gene by Northern blot hybridization. (A) The tissue specificity of FAH mRNA expression was analyzed with FAH cDNA pmcFAH3. Total RNAs were from adult mouse tissues, except for hypothalamus, adrenal gland, and ovary, which were from rat. On longer exposures of the autoradiograph, low levels of FAH mRNA are detected in all lanes. In $B, C$, and $D$, Northern blots identical to those shown in Figs. 1 and 2 were hybridized with pmcFAH3. of FAH mRNA in the liver and kidney, whereas very much lower levels were present in all remaining tissues (Fig. 5A). A phenotype develops in $c^{14 C o S}$ homozygotes by day 16.5 of gestation (e.g., elevated NMO-1; Fig. 1), and we find that FAH mRNA is expressed as early as fetal day 16.5 in both liver and kidney in wild-type mice (Fig. 5B,C). Finally, although no FAH transcripts were detected in $c^{14 C o S} / c^{14 C o S}$ liver, FAH mRNA expression was similar to wild type in newborn liver of the complemented heterozygote $c^{11 D S D} / c^{14 C o S}$ (Fig. 5D).

Because the effects on gene expression and the ultrastructural lesions are restricted to parenchymal cells of the liver and proximal convoluted tubule cells in the kidney (Trigg and Gluecksohn-Waelsch 1973; Ruppert et al. 1990), in situ hybridization was performed to identify the cell types in which FAH mRNA is normally present. Sections of liver and kidney from late fetal and newborn wild-type and $c^{14 C o S} / c^{14 C o S}$ mice were hybridized with antisense probes for FAH, PEPCK, and NMO-1. Hybridizations of kidney sections are shown in Figure 6. In wild-type kidney, PEPCK and FAH hybridization is detected predominantly in proximal tubules (Fig. 6A-D). There was no specific hybridization of the FAH probe to $c^{14 C o S} / c^{14 C o S}$ kidney (Fig. 6E). NMO-1 expression was detected only in $c^{14 \operatorname{Cos}} / c^{14 \operatorname{CoS}}$ kidney (Fig. 6, F and G), and hybridization was also localized to proximal tubule cells (Fig. 6, G and H). In wild-type liver, PEPCK and FAH expression was confined to hepatocytes, and NMO-1 expression was restricted to $c^{14 C o S} / c^{14 C o S}$ hepatocytes (data not shown). Together, these results show a tight correlation between the normal sites and timing of
FAH expression and cells displaying the alf/hsdr-1 deletion phenotype.

\section{Expression of the alf/hsdr-1 deletion phenotype in primary hepatocytes}

Because FAH catalyzes the final step in the breakdown of tyrosine, its deficiency may result in the accumulation of tyrosine metabolites, in particular, maleylacetoacetate (MAA) and fumarylacetoacetate (FAA) (Fig. 3B). These are considered to be the reactive intermediates responsible for initiating the liver damage that accompanies Fah deficiency in man (Kvittingen 1986). The identification that the Fah gene is disrupted by the $c^{14 \text { Cos }}$ deletion raised the possibility that the alterations in gene expression characteristic of the alf/hsdr-1 deletion phenotype are the secondary consequences of toxic effects of FAA and/or MAA. To obtain an indication for this, we attempted to reproduce some aspects of the phenotype in vitro by influencing tyrosine metabolism in cultured hepatocytes.

First, primary hepatocytes were examined for the expression and hormone inducibility of the mRNAs affected by deletion of alf/hsdr-1. Livers were removed from day 17.5 or $18.5 \mathrm{c}^{14 C o s} / \mathrm{c}^{14 C o S}$ (albino) and wildtype (pigmented) fetuses, and cultures of partially enriched hepatocytes were treated with glucocorticoid (dexamethasone) or a cAMP analog (CPT-cAMP) and RNA was prepared. TAT mRNA was not detected in the absence of hormones. However, in both wild-type and $c^{14 \operatorname{Cos}} / c^{14 \operatorname{Cos}}$ hepatocyte cultures, TAT mRNA accumu- 

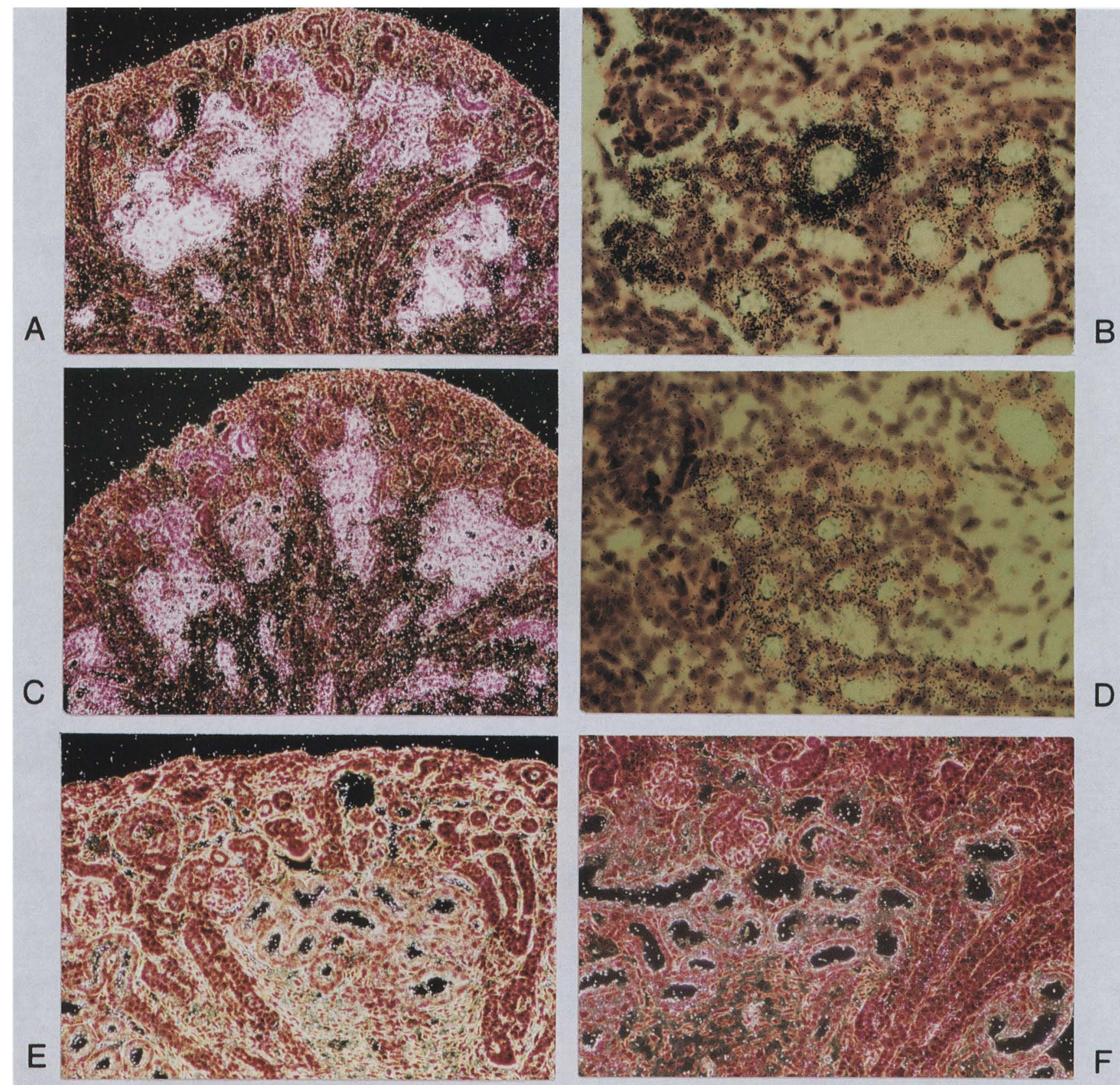

F
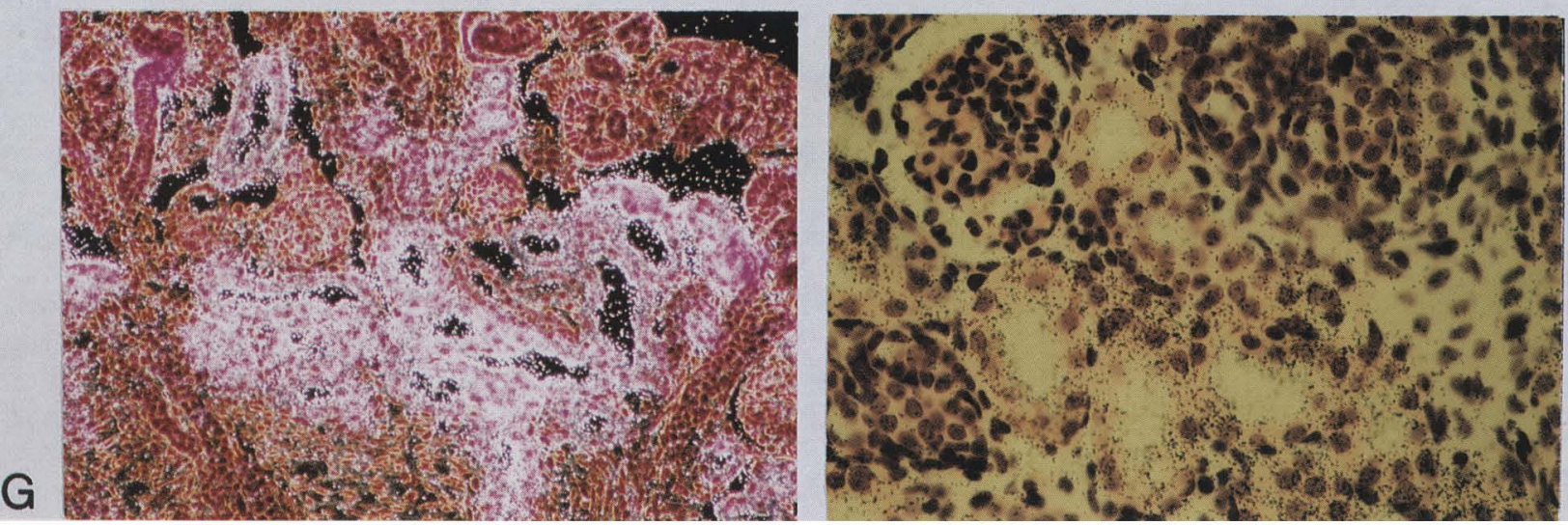

Figure 6. (See facing page for legend.) 
(A)

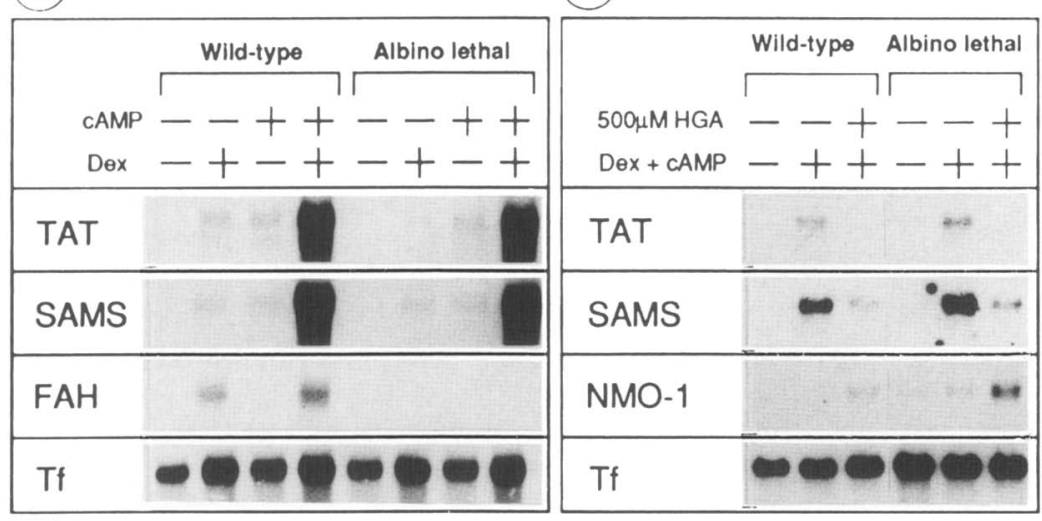

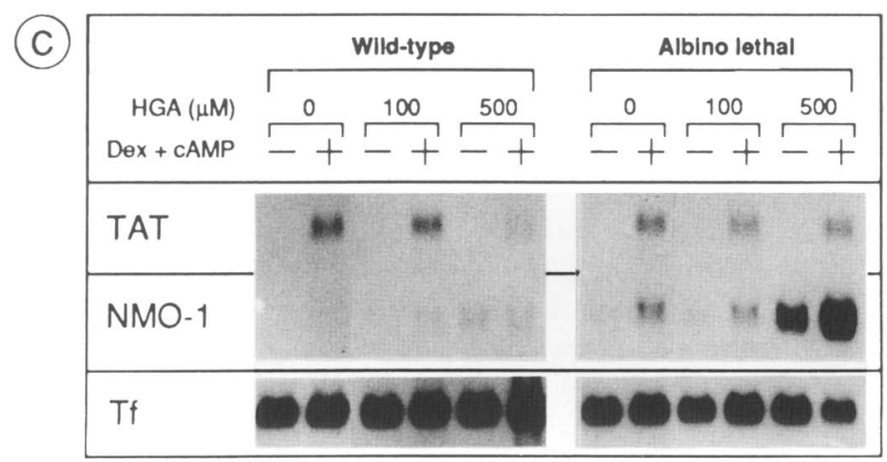

Figure 7. Expression of the alf/hsdr-1 deletion phenotype in primary hepatocytes. (A) Primary hepatocytes from wild-type and lethal albino $\left(c^{14 \operatorname{CoS}} / c^{14 \operatorname{CoS}}\right)$ mice were isolated from day 18 embryos. After 2 days in culture, cells were induced with dexamethasone (Dex), CPT-cAMP (cAMP), dexamethasone plus CPT-cAMP, or mock-induced. Dexamethasone induction was for $16 \mathrm{hr}$; CPT-cAMP for $6 \mathrm{hr}$. Cells were harvested, and Northern analysis was performed on $10 \mu \mathrm{g}$ of total RNA, with the cDNA probes indicated. Hybridization with a transferrin cDNA probe is shown $(\mathrm{Tf})$. $(B)$ Primary hepatocytes from albino lethal $\left(c^{14 \operatorname{CoS}} / c^{14 \operatorname{CoS})}\right.$ and wild-type mice were treated with HGA $(500 \mu \mathrm{M})$ in the presence or absence of dexamethasone and forskolin, which increases cAMP levels after 2 days in culture. Cultures were exposed to dexamethasone plus forskolin for the final $23 \mathrm{hr}$ and HGA for the final $17 \mathrm{hr}$ before harvesting. Four micrograms of total RNA was hybridized to the indicated probes. $(C)$ Primary hepatocytes from lethal albino $\left(c^{14 \mathrm{Cos}}\right)$ $c^{14 C o S} \mid$ and wild-type mice were treated with 100 or $500 \mu \mathrm{M}$ HGA in the presence or absence of dexamethasone and forskolin (cAMP) after 2 days in culture. Exposure to dexamethasone, forskolin, and/or HGA was for $20 \mathrm{hr}$ before harvesting. Five micrograms of total RNA was hybridized to the indicated probes. lated in response to dexamethasone and CPT-CAMP and a combination of the two synergistically induced TAT mRNA to similar high levels in both cultures (Fig. 7A). The mRNA for SAMS behaved in a similar way (Fig. 7A). The origin of the cultures could be verified by detection of FAH mRNA, which appeared only in cultures of wildtype hepatocytes, and was found to be induced by dexamethasone (Fig. 7A). The apparently normal expression

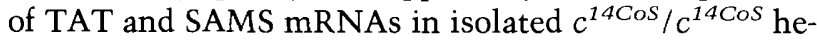
patocytes is in striking contrast to the phenotype in new-

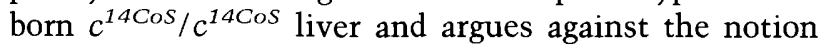
that alf/hsdr-1 encodes a factor that participates directly in the hormone activation or high-level expression of these genes.

To test the effect of an increased intracellular concentration of FAA and/or MAA on gene expression, hepatocyte cultures were exposed to the tyrosine metabolite homogentisate [(HGA) see Fig. 3B]. The use of oral loading of HGA to expose the carrier state in inherited human FAH deficiency (Laberge et al. 1990) was taken as an indication that HGA would be metabolized in hepatocytes and that normal levels of FAH activity could be saturated. In addition, the experience of alkaptonuria, an inborn error of metabolism in which HGA metabolism is blocked (La Du 1989), was taken to indicate that HGA would not itself be toxic to hepatocytes.

HGA treatment $(500 \mu \mathrm{M})$ was found to reduce TAT and SAMS mRNAs in cultures induced with dexamethasone and forskolin close to uninduced levels, both in wildtype and $c^{14 \operatorname{CoS}} / \mathrm{c}^{14 \operatorname{CoS}}$ cells (Fig. 7B). Hybridization with a probe for transferrin indicates that there was no general effect of HGA on mRNA levels. NMO-1 mRNA accumulated in response to HGA treatment, with $c^{14 \operatorname{Cos} /}$ $c^{14 C o S}$ hepatocytes displaying an apparently greater increase (Fig. 7B). A differential response in NMO-1 expression between wild-type and $c^{14 C o S} / c^{14 C o S}$ hepatocytes was seen more clearly in a separate experiment in which different concentrations of HGA were added at the same time as the hormone inducers. In this experiment there was a less pronounced effect of HGA treatment on TAT and SAMS mRNAs (Fig. 7C, and data not shown). HGA induced NMO-1 mRNA in a dose-dependent manner, with a particularly strong increase in $c^{14 \operatorname{Cos}} / \mathrm{c}^{14 \operatorname{CoS}}$ hepatocytes treated with $500 \mu \mathrm{M}$ HGA (Fig. 7C). The increase in NMO-1 mRNA was slightly augmented by hormone treatment, and a significant hormone induction of NMO-1 mRNA was detected in $c^{14 \operatorname{Cos}} / c^{14 \operatorname{Cos}}$ hepatocytes even in the absence of HGA. A stronger effect on

Figure 6. In situ hybridization identifies the major site of $F a h$ gene expression in kidney. Paraffin sections of fetal day 18 wild-type kidney were hybridized with antisense probes for PEPCK $(A, B)$, FAH $(C, D)$, and NMO-1 $(F)$. Sections from fetal day $18 c^{14 C o S}$ homozygous kidney were hybridized with antisense FAH $(E)$ and NMO-1 $(G, H)$ probes. $(A, C, E, F, G)$ Dark-field illumination; $(B, D, H)$ bright-field illumination to reveal predominant localization of grains on tubule cells and absence of grains from glomeruli. 
Ruppert et al.

NMO-1 expression in $c^{14 C o S} / c^{14 C o S}$ hepatocytes is compatible with their inability to clear the tyrosine metabolites because of the lack of FAH. Hormone induction of NMO-1 in $c^{14 C o S} / c^{14 C o S}$ hepatocytes might reflect activation of the tyrosine degradation pathway, because glucocorticoids and cAMP strongly induce TAT, the enzyme catalyzing the first reaction of the pathway. Therefore, these experiments imply that changes in levels of tyrosine metabolites can bring about secondary effects on gene expression characteristic of the alf/hsdr-1 deletion phenotype that are not normally expressed in vitro.

\section{Discussion}

Identification of the Fah gene as a candidate for alf/hsdr-1

In this paper we show that two aspects of the $c^{14 \operatorname{Cos}}$ phenotype, the reduced expression of hormone-inducible genes and induction of NMO-1 mRNA, depend on loss of the most proximal $\sim 315 \mathrm{~kb}$ of the $\sim 3800-\mathrm{kb} c^{14 \operatorname{CoS}} \mathrm{de}-$ letion, the same region that is essential for neonatal survival (Russell et al. 1982; Schedl et al. 1992). In addition, both negative and positive effects on gene expression, as well as the ultrastructural lesions (Trigg and Gluecksohn-Waelsch 1973), are restricted to the same two cell types. Therefore, it is probable that these abnormalities result from the absence of a single gene, located partly or entirely in this $\sim 315-\mathrm{kb}$ region. Zoo blot and Northern analysis with probes from this region identified the gene for FAH. The Fah gene has been identified independently by Klebig et al. (1992).

Three lines of evidence strongly support Fah as a candidate gene for alf/hsdr-1. First, there is a striking concordance between the cell types that normally express high-levels of FAH mRNA and those in which the phenotype develops. Second, inherited FAH deficiency in man leads to a fatal infant liver disease (Kvittingen 1986), which has suggestive parallels with the alf/hsdr-1 deletion phenotype. Third, based on the knowledge that FAH is an enzyme of tyrosine metabolism, we induced changes in gene expression in cultured hepatocytes similar to those seen in the mutant liver by treatment with a tyrosine metabolite. Recently, we have been able to show that an FAH cDNA transgene can restore viability to $c^{14 \operatorname{CoS}}$ homozygotes (G. Kelsey, S. Ruppert, and F. Beermann, unpubl.).

\section{Accumulation of reactive tyrosine metabolites could cause the alf/hsdr-1 deletion phenotype}

The $c^{14 \operatorname{CoS}}$ phenotype was interpreted as indicating that the deletion removes a locus, alf or $h s d r-1$, required for perinatal activation of hormone-dependent genes in liver (Gluecksohn-Waelsch 1987; McKnight et al. 1989; Ruppert et al. 1990). In addition, a locus encoding a repressor of the Nmo-1 and gadd genes, designated Nmo-1n, has been proposed to map within the deletion (Petersen et al. 1989; Nebert et al. 1990). It might seem surprising that we should advance a gene for a metabolic enzyme, FAH, as a candidate for both alf/hsdr-1 and Nmo-1n, but we can now offer an alternative explanation for the $c^{14 C o s}$ deletion phenotype.

FAH deficiency blocks the tyrosine degradation pathway beyond the hydrolysis of FAA. FAA is strongly electrophilic, adducts rapidly with glutathione (Edwards and Knox 1956; Laberge et al. 1990), and could react with thiol or other nucleophilic groups on macromolecules. Although toxicity of FAA has not been shown directly, it is suspected to be an alkylating agent and is presumed to initiate the cellular damage accompanying FAH deficiency in man (Lindblad et al. 1977; Kvittingen 1986; Laberge et al. 1986). The consequences of an accumulation of FAA in perinatal mouse liver might be expected to include early responses, which attempt to detoxify the liver and repair damage caused, and secondary effects, such as those on gene expression.

An early detoxification response could be the elevated expression of NMO-1. NMO-1 is induced by and metabolizes a wide variety of xenobiotics (Talalay and Prochaska 1987; Lind et al. 1990), although inducers seem to be characterized by electrophilic olefin or acetylene bonds (Talalay et al. 1988). FAA posseses an olefinic bond flanked by electron-withdrawing keto and/or carboxyl groups (Fig. 3B), which suggests that it falls into this class of inducers. Consistent with a detoxifying role, NMO-1 mRNA is strongly elevated in $c^{14 C o s}$ homozygotes in the cell types that should normally contain the highest levels of FAH, those in which tyrosine degradation predominates, and is among the earliest components of the phenotype (this paper; Petersen et al. 1989). The possibility that abnormal concentrations of tyrosine metabolites can lead to NMO-1 induction is reinforced by the sensitivity of NMO-1 mRNA levels in cultured

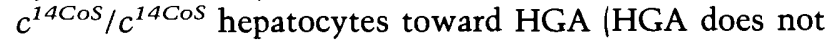
have the same electrophilic character as FAA). In this context, it is interesting that activities of GST B and UDP-glucuronosyltransferase-two other enzymes involved in detoxification and, like NMO-1, members of the $(A h)$ battery-were found to be increased in newborn $c^{14 C o S} / c^{14 C o S}$ livers more than a decade ago (Thaler et al. 1976; Gatmaitan et al. 1977).

A second component of the early response to FAA may be the induction of gadd transcripts: gadd153 mRNA is present already at fetal day 16 in $c^{14 C o S} / c^{14 C o S}$ liver (Fornace et al. 1989). The gadd genes were identified on the basis of induction by DNA damage (Fornace et al. 1988). The three gadd transcripts elevated in $c^{14 C o s} / c^{14 C o s}$ belong to a class most sensitive to DNA damage by alkylating agents (Fornace et al. 1989), and might owe their induction to the presumed alkylating properties of FAA. Expression of the early response gene c-fos is also responsive to DNA damage by alkylating agents (Hollander and Fornace 1989), and the sustained, high-level expression of FOS mRNA in $c^{14 C o S} / c^{14 C o S}$ liver might be a manifestation of this.

Overt signs of intracellular damage in $c^{14 C o s} / c^{14 C o S}$ mice are the intracellular membrane abnormalities that become apparent at fetal day 18 and, like other aspects of the phenotype, are confined to liver and kidney (Trigg 
and Gluecksohn-Waelsch 1973). These lesions might arise from alkylation of membrane components or oxidative stress.

The final component of the $c^{14 C o s}$ phenotype is the reduced expression of hormone-dependent genes that becomes most pronounced around birth, a timing consistent with an effect secondary to cellular responses or damage elicited by FAA. The sequence of events leading to reduced expression of any one of the affected genes may be complex and brought about by a combination of factors (as discussed below).

It might seem paradoxical that consequences of $\mathrm{FAH}$ deficiency should occur in fetal liver and kidney, while high-level expression of TAT, the enzyme catalyzing the first step in tyrosine degradation, develops exclusively in the liver around birth and is severely reduced in $c^{14 \operatorname{Cos}}$ homozygotes. The explanation for this paradox seems to be that tyrosine is also deaminated by aspartate aminotransferase, which is active in several mammalian tissues, including fetal liver and kidney (Fellman et al. 1972a; Yeoh et al. 1979; Hargrove and Mackin 1984l, and is not reduced in $c^{14 C o S} / c^{14 C o S}$ liver (Thorndike et al. 1973). The phenotype is restricted to the liver and kidney because generation of the most damaging tyrosine metabolites is limited by the tissue specificity of subsequent enzymes in the pathway (Fellman et al. 1972b).

\section{The failure of perinatal activation of hormone-dependent genes}

The failure to activate hormone-dependent genes, such as TAT and PEPCK (Schmid et al. 1985; Loose et al. 1986), is the aspect of the alf/hsdr-1 deletion phenotype that has generated the most interest. Inducibility by glucocorticoids and/or the cAMP pathway was found to be a property common to mRNAs reduced in mutant liver (Ruppert et al. 1990). A selective effect on hormone-inducibility was suggested, moreover, by the impaired glucocorticoid, but normal heavy metal, response of the metallothionein gene $M t-1$ in mutant livers (DeFranco et al. 1988). One observation that casts doubt on the notion that alf/hsdr-1 encodes a factor that participates directly in hormonal activation, however, and that is easier to reconcile with a secondary effect on gene expression, is our finding that the TAT and SAMS genes displayed equally strong hormone responses in $c^{14 C o S} / c^{14 C o S}$ and wild-type hepatocytes cultured from fetal livers. The unimpaired hormone response of primary cultures of $c^{14 C o S} / c^{14 C o S}$ hepatocytes suggests that tyrosine metabolites do not normally reach harmful levels in cultured hepatocytes, at least under our culture conditions.

Three mechanisms contributing to the failure to activate hormone-dependent genes can be envisaged considering that the signal transduction pathways for glucocorticoids and cAMP are apparently intact (Ruppert et al. 1990; DeFranco et al. 1991). The first might involve reduced expression of transcription factors: The mRNAs for hepatic nuclear factors HNF-1 and HNF-4 are affected most strongly (Gonzalez et al. 1990; Tönjes et al. 1992), while HNF-3 and C/EBP show modest reductions (Mc-
Knight et al. 1989; Ruppert et al. 1990; Tönjes et al. 1992). One or more of these factors might be required for hormone-dependent and/or high-level expression of the TAT and PEPCK genes. The liver-specific enhancer 3.6 $\mathrm{kb}$ upstream of the rat TAT gene (Boshart et al. 1990) contains a cAMP-responsive element recognized by cAMP-responsive element binding (CREB) protein (Nichols et al. 1992) and a binding site for HNF-4 (D. Niewolik, pers. comm.). Both elements are required for enhancer function (Boshart et al. 1990). Similarly, the glucocorticoid-dependent enhancer at $-2.5 \mathrm{~kb}$ of the rat TAT gene not only contains binding sites for the glucocorticoid receptor (GR) but also for other factors (Becker et al. 1986; Reik et al. 1991), which might include CCAAT box/enhancer-binding protein (C/EBP) (Grange et al. 1991) and HNF-3 (D. Nitsch, pers. comm.). These accessory factors are likely to be essential for full function of the $-2.5-\mathrm{kb}$ enhancer (Jantzen et al. 1987; D. Niewolik, pers. comm.).

A second mechanism is suggested by the recent discovery that the product of the gadd153 gene, which is elevated early in $c^{14 C o S} / c^{14 C o S}$ liver (Fornace et al. 1989), is homologous to CHOP-10 (Ron and Habener 1992). CHOP-10 was identified by its ability to form heterodimers with the transcription factors $\mathrm{C} / \mathrm{EBP} \alpha$ and $\mathrm{C} / \mathrm{EBP} \beta$ via a leucine zipper. CHOP-10 prevents recognition of $\mathrm{C} / \mathrm{EBP}$-binding sites by $\mathrm{C} / \mathrm{EBP} \alpha$ and $\mathrm{C} / \mathrm{EBP} \beta$ and inhibits trans-activation of C/EBP-dependent promoters (Ron and Habener 1992).

Third, we detected a high and sustained level of c-fos transcripts in $c^{14 \operatorname{CoS}} / c^{14 \operatorname{CoS}}$ liver before and after birth, which might be related to alkylation damage induced by FAA. Transfection studies have suggested that FOS protein can antagonize glucocorticoid induction (Jonat et al. 1990; Lucibello et al. 1990; Yang-Yen et al. 1990; Shemshedini et al. 1991), although the mechanism is unclear. In rat hepatoma cells treated with the phorbol ester TPA, induction of FOS mRNA is associated with decreased glucocorticoid-induced levels of TAT mRNA (A. Reik, pers. comm.).

The alf/hsdr-1-deficient mouse as model for the human genetic disease tyrosinemia type I

The greatest hint that absence of FAH could be responsible for the alf/hsdr-1 deletion phenotype came from comparison with the human deficiency state. FAH deficiency is the primary defect in the autosomal recessive disease hereditary tyrosinemia type I (HT), a well-characterized disorder of tyrosine metabolism (Kvittingen 1986; Goldsmith and Laberge 1989). In its more common, acute form, HT presents as an infantile liver failure, and death normally ensues within a few months of birth unless the liver is transplanted. More chronic liver failure is associated with residual enzyme activity and protein (Tanguay et al. 1990) and is characterized by a high incidence of hepatocellular carcinoma in the first decade of life (Weinberg et al. 1976; Russo and O'Regan 1990 ). In contrast to the relatively more protracted human disease, the alf/hsdr-1 phenotype is highly uniform 
and lethality occurs a few days after the first manifestations of FAH deficiency. Because abnormalities in FAH deficiency arise from the presence of harmful tyrosine metabolites, the phenotype depends, in part, on the ability to detoxify these compounds. In addition, the human and mouse phenotypes that can be compared are diverse secondary effects arising from the same primary defect. The example of hypoxanthine phosphoribosyltransferase deficiency in man (Lesch-Nyhan syndrome) and mouse underscores the importance of secondary metabolic differences in determining very different outcomes (Hooper et al. 1987; Kuehn et al. 1987). Nevertheless, the comparison with HT supports our conclusion that FAH deficiency is the basis for neonatal lethality in $c^{14 \operatorname{Cos} /}$ $c^{14 C o S}$ mice. Abnormalities are most pronounced in the two organs that normally express the highest levels of FAH and are active in tyrosine degradation: The limitation of ultrastructural and histological changes to these organs is consistent with a very local site of action of the damaging intermediates (Trigg and Gluecksohn-Waelsch 1973; Dehner et al. 1989; Russo and O'Regan 1990). Some of the enzymes in which expression is strongly reduced in $c^{14 C o S} / c^{14 C o S}$ mice have been assayed in HT material. Decreases in TAT activity have been described Gaull et al. 1970; Furukawa et al. 1984; Stoner et al. 1984; Laberge et al. 1985), as well as reductions in SAMS and other enzymes of methionine metabolism /Gaull et al. 1970|. It will be of great interest to investigate whether other changes characteristic of the alf/hsdr-1 deletion phenotype are represented in HT. We envisage that the $c^{14 \operatorname{Cos}} / \mathrm{c}^{14 \operatorname{CoS}}$ mouse will provide a useful model that will deepen the understanding of FAH deficiency in man.

\section{Materials and methods}

Construction of cDNA libraries, isolation and characterization of FAH CDNA clones

Poly $(\mathrm{A})^{+}$RNA from livers of newborn $c^{c h} / c^{c h}$ mice was used for construction of a directional cDNA library in AZAPII (Stratagene), essentially as described previously (Ruppert et al. 1988; Schöler et al. 1990). Of the original $5 \times 10^{7}$ recombinants, $3 \times 10^{5}$ PFU were amplified on Escherichia coli PLK- $F^{\prime}$ and screened with probes from genomic clones RN.Fa and RN.Fd (Schedl et al. 1992). Twelve independent cDNA clones were isolated and characterized by restriction enzyme analysis and DNA sequencing from their $5^{\prime}$ and $3^{\prime}$ ends (Luckow and Schütz 1991). Sequencing of the coding region of four cDNAs, including pmcFAH7 and pmcFAH3, was completed with internal oligonucleotide primers. A detailed description of the FAH cDNA and genomic clones will be presented elsewhere (G. Kelsey, unpubl.).

\section{RNA preparation and Northern blot analysis}

Fetal liver and kidney RNAs were prepared from albino $\left(c^{14 \operatorname{Cos} /}\right.$ $\left.c^{14 C o S}\right)$ and wild-type mice from organs pooled from each stage, and tissue RNAs were prepared from wild-type adult mice and rats as described previously (Ruppert et al. 1990). Liver RNAs for time points after birth have been described (Ruppert et al. 1990). Northern blot analysis with antisense riboprobes was performed as described previously (Ruppert et al. 1990).

\section{Southern blot analysis}

Southern blot analysis of albino deletion DNAs was performed as described previously (Kelsey et al. 1992). Hybridization was with a gel-purifed insert from pmcFAH3 labeled by random priming (Feinberg and Vogelstein 1984).

\section{In situ hybridization}

Livers and kidneys of day 18 lethal albino $\left(c^{14 \operatorname{Cos}} / c^{14 \operatorname{CoS}}\right)$ and normal littermates $\left[c^{c h} / c^{c h}\right.$ or $\left.c^{c h} / c^{14 C o S}\right\}$ were fixed in $4 \%$ paraformaldehyde and embedded in paraffin according to Duboule and Dollé (1989). Hybridizations were performed on 5to $10-\mu \mathrm{m}$ sections with sense and/or antisense RNA probes for FAH, PEPCK, and NMO-1 labeled with $\left[\alpha{ }^{-35}\right.$ S JUTP (Duboule and Dollé 1989). Sections were exposed for 4-19 days, developed with Kodak D19, and counterstained with hematoxylin and eosin.

\section{Probes used in this analysis}

Probes for TAT, PEPCK, and X1 have been described (Ruppert et al. 1990). cDNAs X2 and X5 (Ruppert et al. 1990) have been identified to correspond to SAMS and CoAS, respectively, by recent sequence comparisons (Horikawa et al. 1989; Ayté et al. 1990; details available on request). The FAH probe was the near full-length cDNA clone pmcFAH3, which contains a deletion of untranslated sequences at the $3^{\prime}$ end of the cDNA. A probe for NMO-1 was made by polymerase chain reaction (PCR) with oligonucleotides corresponding to position 41-5'-CTTGACACTAGGATCCGCCCCCAACTTCTGG-3'-and position 885-5'-CTAGCTTAGATCTGGTTGTCGGCTGGAATCC-3' - of the rat $\mathrm{NMOR}_{1}$ CDNA (Robertson et al. 1986) and containing engineered BamHI and BglII restriction sites. Reverse transcription/PCR was performed on RNA from the rat hepatoma cell line FTO-2B, under conditions described by Ruppert et al. (1992), and an 850-bp BamHI-BglII fragment was subcloned into Bluescribe (Stratagene) to yield plasmid prcNMOR. Identity to the published sequence was confirmed by partial sequence analysis.

\section{Isolation and culture of fetal hepatocytes}

Primary hepatocyte cultures were prepared as described by Yeoh et al. (1979) with slight modifications. Hepatocytes enriched from livers of day 17.5 albino $\left(c^{14 C o S} / c^{14 C O S}\right)$ and normal littermates $\left(c^{c h} / c^{c h}\right.$ or $\left.c^{c h} / c^{14 C o S}\right)$ were plated at a density of approximately two livers per 5 -cm collagen-coated culture dish in Dulbecco's modified Eagle medium (DMEM)/HamF12 medium containing $10 \%$ fetal calf serum, insulin $(1 \mu \mathrm{g} / \mathrm{ml})$, penicillin $(100 \mathrm{U} / \mathrm{ml})$, and streptomycin sulfate $(100 \mu \mathrm{g} / \mathrm{ml})$. Cells were cultured for 2-3 days before induction with hormones in media lacking insulin. Glucocorticoid induction was for the final $17 \mathrm{hr}(1 \mu \mathrm{M}$ dexamethasone $)$ and cAMP induction $10.5 \mathrm{mM}$ p-chlorophenylthio-cAMP; CPT-cAMP, Boehringer Mannheim) was for the final $5 \mathrm{hr}$ before harvesting. Two conditions of HGA treatment were used. After 2 days of culture, hepatocytes were induced with $1 \mu \mathrm{M}$ dexamethasone and $10 \mu \mathrm{M}$ forskolin, $500 \mu \mathrm{M}$ HGA (Sigma) was added after $6 \mathrm{hr}$, and cells were cultured $17 \mathrm{hr}$ before harvesting. Alternatively, HGA (100 or $500 \mu \mathrm{M})$ was added at the same time as dexamethasone $(1 \mu \mathrm{M})$ and forskolin $(10 \mu \mathrm{M})$, and cells were harvested $20 \mathrm{hr}$ later. RNAs were prepared according to Chomczynski and Sacchi (1987). 


\section{Acknowledgments}

We thank S. Gluecksohn-Waelsch (Albert Einstein School of Medicine, Bronx, NY) for providing $c^{14 \operatorname{Cos}}$ mice, $\mathrm{T}$. Magnuson (Case Western Reserve University, Cleveland, $\mathrm{OH}$ ) for providing livers from $c^{11 D S D} / c^{14 C o S}$ heterozygotes and their normal littermates, and M.L. Klebig and E.M. Rinchik /Oak Ridge National Laboratory, Oak Ridge, TN) for providing $c^{10 R 75 M} / c^{1 O R 75 M}$ DNA. G. Yeoh gave us valuable initial help in the preparation of primary hepatocytes. We are grateful to B. Luckow and T.J. Cole for computer analysis, M. Boshart and T.J. Cole for their critical reading of the manuscript and helpful suggestions, G. Withers and W. Fleischer for photographic work, W. Fleischer for oligonucleotide synthesis, and C. Schneider for excellent secretarial assistance. This work was supported by the Deutsche Forschungsgemeinschaft through SFB 229 and the Leibniz Programm, and the Fonds der Chemischen Industrie.

The publication costs of this article were defrayed in part by payment of page charges. This article must therefore be hereby marked "advertisement" in accordance with 18 USC section 1734 solely to indicate this fact.

\section{Note added in proof}

The FAH amino acid sequence has been deposited in the EMBL/ GenBank data libraries.

\section{References}

Agsteribbe, E., H. van Fassen, M.V. Hartog, T. Revesma, J.W. Taanman, H. Pannekoek, R.F. Evers, G.M. Welling, and R. Berger. 1990. Nucleotide sequence of cDNA encoding human fumarylacetoacetase. Nucleic Acids Res. 18: 1887.

Ayté, J., G. Gil-Gonzalez, D. Haro, P.F. Marrero, and F.G. Hegardt. 1990. Rat mitochondrial and cytosolic 3-hydroxy-3methyl-CoA synthases are encoded by two different genes. Proc. Natl. Acad. Sci. 87: 3874-3878.

Baier, L.J., S.M. Hanash, and R.P. Erickson. 1984. Mice homozygous for chromosomal deletions at the albino locus region lack specific polypeptides in two-dimensional gels. Proc. Natl. Acad. Sci. 81: 2132-2136.

Becker, P.B., B. Gloss, W. Schmid, U. Strähle, and G. Schütz. 1986. In vivo protein-DNA interactions within a glucocorticoid response element require presence of the hormone. $\mathrm{Na}$ ture 324: 686-688.

Boshart, M., F Weih, A. Schmidt, R.E.K. Fournier, and G. Schütz. 1990. A cyclic AMP response element mediates repression of tyrosine aminotransferase gene transcription by tissue-specific extinguisher locus Tse-1. Cell 61: 905-916.

Chomczynski, P. and N. Sacchi. 1987. Single-step method of RNA isolation by acid guanidinium thiocyanate-phenolchloroform extraction. Anal. Biochem. 162: 156-159.

DeFranco, D., S.M. Morris, C.M. Leonard, and S. GluecksohnWaelsch. 1988. Metallothionein mRNA expression in mice homozygous for chromosomal deletions around the albino locus. Proc. Natl. Acad. Sci. 85: 1161-1164.

DeFranco, D., D. Bali, R. Torres, R.A. DePinho, R.P. Erickson, and S. Gluecksohn-Waelsch. 1991. The glucocorticoid hormone signal transduction pathway in mice homozygous for chromosomal deletions causing failure of cell type-specific inducible gene expression. Proc. Natl. Acad. Sci. 88: 56075610 .

Dehner, L.P., D.C. Snover, H.L. Sharp, N. Ascher, R. Nakhleh and D.L. Day. 1989. Hereditary tyrosinemia type I (chronic form): Pathological findings in liver. Hum. Pathol. 20: 149158.

Donner, M.E., C.E. Leonard, and S. Gluecksohn-Waelsch. 1988.
Developmental regulation of constitutive and inducible expression of hepatocyte-specific gene expression in the mouse. Proc. Natl. Acad. Sci. 85: 3049-3051.

Duboule, D. and P. Dollé. 1989. The structural and functional organization of the murine HOX gene family resembles that of Drosophila homeotic genes. EMBO I. 8: 1497-1505.

Edwards, S.W. and W.E. Knox. 1956. Homogentisate metabolism: the isomerization of maleylacetoacetate by an enzyme which requires glutathione. J. Biol. Chem. 220: 79-91.

Erickson, R.P., S. Gluecksohn-Waelsch, and C. Cori 1968. Glucose-6-phosphatase deficiency caused by radiation-induced alleles at the albino locus in the mouse. Proc. Natl. Acad. Sci. 59: 437-444.

Feinberg, A.P. and B. Vogelstein. 1984. A technique for radiolabeling DNA restriction endonuclease fragments to high specific activity (Addendum). Anal. Biochem. 137: 266-267.

Fellman, J.H., N.R.M. Buist, N.G. Kennaway, and R.E. Swanson. 1972a. The source of aromatic ketoacids in tyrosinemia and phenylketonuria. Clin. Chim. Acta 39: 243-246.

Fellman, J.H, T.S. Fujita, and E.S. Roth. 1972b. Assay, properties and tissue distribution of $p$-hydroxyphenylpyruvate hydroxylase. Biochim. Biophys. Acta 284: 90-100.

Fornace, A.J. Jr., I. Alamo Jr., and M.C. Hollander 1988. DNA damage-inducible transcripts in mammalian cells. Proc. Nat1. Acad. Sci. 85: 8800-8804.

Fornace, A.J. Jr., D.W. Nebert, M.C. Hollander, J.D. Luethy, M. Papathanasiou, J. Fargnoli, and N.J. Holbrook. 1989. Mammalian genes coordinately regulated by growth arrest signals and DNA-damaging agents. Mol. Cell. Biol. 9: 4196-4203.

Furukawa, N., T. Hayano, N. Sato, Y. Machida, A. Kinugasa, S. Imashuku, T. Kusunoki, and T. Takmatisu. 1984. The enzyme defects in hereditary tyrosinemia type I. I. Inherited Metab. Dis. (Suppl. 2) 7: 137-138.

Gatmaitan, Z., S. Lewis, H. Turchin, and I.M. Arias. 1977. Premature development of ligandin (GSH transferase B) in mice with an inherited defect in endoplasmic reticulum-Golgi structure and function. Biochem. Biophys. Res. Commun. 75: $337-341$.

Gaull, G.E., D.K. Rassin, G.E. Solomon, R.C. Harris, and J.A. Sturman. 1970. Biochemical observations on so-called hereditary tyrosinemia. Pediatr. Res. 4: 337-344.

Gluecksohn-Waelsch, S. 1979. Genetic control of morphogenetic and biochemical differentiation: Lethal albino deletions in the mouse. Cell 16: 225-237.

- 1987. Regulatory genes in development. Trends Genet. 3: 123-127.

Goldsmith, L.A. and C. Laberge. 1989. Tyrosinemia and related disorders. In The metabolic basis of inherited disease, 6th ed. (ed. C.R. Scriver, A.L. Beaudet, W.S. Sly, and D. Valle), pp. 547-562. McGraw-Hill, New York.

Gonzalez, F.J., S.-Y. Liu, C.A. Kozak, and D.W. Nebert. 1990. Decreased Hnf-1 gene expression in mice homozygous for a 1.2-centiMorgan deletion on chromosome 7. DNA Cell Biol. 9: 771-776.

Grange, T., J. Roux, G. Rigaud, and R. Pictet. 1991. Cell-type specific activity of two glucocorticoid responsive units of rat tyrosine aminotransferase gene is associated with multiple binding sites for C/EBP and a novel liver-specific nuclear factor. Nucleic Acids Res. 19: 131-139.

Hargrove, I.L. and R.B. Mackin. 1984. Organ specificity of glucocorticoid-sensitive tyrosine aminotransferase: Separation from aspartate aminotransferase isoenzymes. I. Biol. Chem. 259: 386-393.

Hollander, M.C. and A.J. Fornace Jr. 1989. Induction of fos RNA by DNA-damaging agents. Cancer Res. 49: 1687-1692.

Hooper, M., K. Hardy, A. Handyside, S. Hunter, and M. Monk. 
1987. HPRT deficient (Lesch-Nyhan) mouse embryos derived from germline colonisation by cultured cells. Nature 326: 292-294.

Horikawa, S., M. Ishikawa, H. Ozasa, and K. Tsukada. 1989. Isolation of a cDNA encoding the rat liver $S$-adenosylmethionine synthetase. Eur. J. Biochem. 184: 497-501.

Jantzen, H.-M., U. Strähle, B. Gloss, F. Stewart, W. Schmid, M. Boshart, R. Miksicek, and G. Schütz. 1987. Cooperativity of glucocorticoid response elements located far upstream of the tyrosine aminotransferase gene. Cell 49: 29-38.

Jonat, C., H.J. Rahmsdorf, K.-K. Park, A.C.B. Cato, S. Gebel, H. Ponta, and P. Herrlich. 1990. Antitumor promotion and antiinflammation: Down-modulation of AP-1 (Fos/Jun) activity by glucocorticoid hormone. Cell 62: 1189-1204.

Kelsey, G., A. Schedl, S. Ruppert, L. Niswander, T. Magnuson, M.L. Klebig, E.M. Rinchik, and G. Schütz. 1992. Physical mapping of the albino-deletion complex in the mouse to localize alf/hsdr-1, a locus required for neonatal survival. Genomics (in press).

Klebig, M.L., L.B. Russell, and E.M. Rinchik. 1992. Murine fumarylacetoacetate hydrolase $(F a h)$ gene is disrupted by a neonatally lethal albino deletion that defines the hepatocyte-specific developmental regulation 1 (hsdr-1) locus. Proc. Natl. Acad. Sci. 89: 1363-1367.

Kuehn, M.R., A. Bradley, E.J Robertson, and M.J Evans. 1987. A potential animal model for Lesch-Nyhan syndrome through introduction of HPRT mutations into mice. Nature 326: 295-298.

Kvittingen, E.A. 1986. Hereditary tyrosinemia type I: An overview. Scand. J. Clin. Lab. Invest. 46: 27-34.

Laberge, C., A. Grenier, J.-P. Valet, and A. Lescault. 1985. AFP in newborn screening for tyrosinemias: The Quebec experience, 1983. In Alpha-fetoprotein and congenital disorders (ed. G.J. Mizejewski and I.H. Porter), pp. 123-137. Academic Press, Orlando, FL.

Laberge, C., A. Lescault, and R.M. Tanguay. 1986. Hereditary tyrosinemias (type I): A new vista on tyrosine toxicity and cancer. In Essential nutrients in carcinogenesis led. L.A. Poirier, P.M. Newbarne, and M.W. Parizal, pp. 209-221. Plenum Press, New York.

Laberge, C., A. Lescault, A. Grenier, J. Morrisette, R. Gagné, P. Gadbois, and J. Halket. 1990. Oral loading of homogentisic acid in controls and in obligate heterozygotes for hereditary tyrosinemia type I. Am. J. Hum. Genet. 47: 329-337.

La Du, B.N. 1989. Alcaptonuria. In The metabolic basis of inherited disease, 6th ed. (ed. C.R. Scriver, A.L. Beaudet, W.S. Sly, and D. Valle), pp. 775-790. McGraw-Hill, New York.

Lind, C., E. Cadenas, P. Hochstein, and L. Ernster. 1990. DTdiaphorase: Purification, properties, and function. Methods Enzymol. 186: 287-301.

Lindblad, B., S. Lindstedt, and G. Steen. 1977. On the enzymatic defects in hereditary tyrosinemia. Proc. Natl. Acad. Sci. 74: 4641-4645.

Loose, D.S., P.A. Shaw, K.S. Krauter, C. Robinson, S. Englard, R.W. Hanson, and S. Gluecksohn-Waelsch. 1986. Transregulation of the phosphoenolpyruvate carboxykinase (GTP) gene, identified by deletions in chromosome 7 of the mouse. Proc. Natl. Acad. Sci. 83: 5184-5188.

Lucibello, F.C., E.P. Slater, K.U. Jooss, M. Beato, and R. Müller. 1990. Mutual transrepression of Fos and the glucocorticoid receptor: Involvement of a functional domain in Fos which is absent in FosB. EMBO J. 9: 2827-2834.

Luckow, B. and G. Schütz. 1991. Linker scanning mutagenesis. In Directed mutagenesis: A practical approach (ed. M. McPhersen), pp. 101-133. IRL Press, Oxford, England.

McKnight, S.L., M.D. Lane, and S. Gluecksohn-Waelsch. 1989.
Is CCAAT/enhancer-binding protein a central regulator of energy metabolism? Genes \& Dev. 3: 2021-2024.

Morris, S.M. Jr., C.L. Moncman, D.M. Kepka, V.L. Nebes, W.F. Diven, G.J. Dizikes, S.D. Cederbaum, and D. DeFranco. 1988. Effects of deletions in mouse chromosome 7 on expression of genes encoding the urea-cycle enzymes and phosphoenolpyruvate carboxykinase (GTP) in liver, kidney, and intestine. Biochem. Genet. 26: 769-781.

Nebert, D.W., D.D. Petersen, and A.J. Fornace Jr. 1990. Cellular responses to oxidative stress: The $[A h]$ gene battery as a paradigm. Environ. Health Perspect. 88: 13-25.

Nichols, M., F. Weih, W. Schmid, C. DeVack, E. Kowenz-Leutz, B. Luckow, M. Boshart and G. Schütz. 1992. Phosphorylation of CREB affects its binding to high and low affinity sites: implications for CAMP induced gene expression. $E M B O F$. (in press).

Petersen, D.D., F.J. Gonzalez, V. Rapic, C.A. Kozak, J.-Y. Lee, J.E. Jones, and D.W. Nebert. 1989. Marked increase in hepatic $\mathrm{NAD}(\mathrm{P}) \mathrm{H}$ :oxidoreductase gene transcription and mRNA levels correlated with a mouse chromosome 7 deletion. Proc. Natl. Acad. Sci. 86: 6699-6703.

Phaneuf, D., Y. Labelle, D. Berube, K. Arden, W. Cavenee, R. Gagne, and R.M. Tanguay. 1991. Cloning and expression of the cDNA encoding human fumarylacetoacetate hydrolase, the enzyme deficient in hereditary tyrosinemia: Assignment of the gene to chromosome 15. Am. J. Hum. Genet. 48: 525535.

Reik, A., G. Schütz, and A.F. Stewart. 1991. Glucocorticoids are required for establishment and maintenance of an alteration in chromatin structure: Induction leads to a reversible disruption of nucleosomes over an enhancer. EMBO $\mathrm{I}$. 10: $2569-2576$.

Rinchik, E.M. and L.B. Russell. 1990. Germ-line deletion mutations in the mouse: Tools for intensive functional and physical mapping of regions of the mammalian genome. In Genetic and physical mapping. Genome analysis (ed. K.E. Davies and S.M. Tilghman), vol. 1, pp. 121-158. Cold Spring Harbor Laboratory Press, Cold Spring Harbor, New York.

Robertson, J.A., H-C. Chen, and D.W. Nebert. 1986. NAD(P)H:menadione oxidoreductase. Novel purification of enzyme, cDNA and complete amino acid sequence, and gene regulation. I. Biol. Chem. 261: 15794-15799.

Ron, D. and J.F. Habener. 1992. CHOP, a novel developmentally regulated nuclear protein that dimerizes with transcription factors C/EBP and LAP and functions as a dominant negative inhibitor of gene transcription. Genes \& Dev. 6: 439453.

Ruppert, S. 1988. "Die Albino-Letal-Mutation der Maus: Koordinierte Regulation leberspezifischen Gene durch zwei genetisch definierte Loci und molekulare Charakterisierung des Albino-Locus." Ph.D. thesis. University of Heidelberg, Germany.

Ruppert, S., G. Müller, B. Kwon, and G. Schütz. 1988. Multiple transcripts of the mouse tyrosinase gene are generated by alternative splicing. $E M B O /$. 7: 2715-2722.

Ruppert, S., M. Boshart, F.X. Bosch, W. Schmid, R.E.K. Fournier, and G. Schütz. 1990. Two genetically defined trans-acting loci coordinately regulate overlapping sets of liver-specific genes. Cell 61: 895-904.

Ruppert, S., T.J. Cole, M. Boshart, E. Schmid, and G. Schütz. 1992. Multiple mRNA isoforms of the transcriptional activator protein CREB: Generation by alternative splicing and specific expression in primary spermatocytes. EMBO $\mathrm{I}$. 11: 1503-1512.

Russell, L.B., C.S. Montgomery, and G.D. Raymer. 1982. Analysis of the albino-locus region of the mouse. IV. Character- 
ization of 34 deficiencies. Genetics 100: 427-453.

Russo, P. and S. O'Regan. 1990. Visceral pathology of hereditary tyrosinemia type I. Am. I. Hum. Genet. 47: 317-324.

Schedl, A., S. Ruppert, G. Kelsey, E. Thies, L. Niswander, T. Magnuson, M.L. Klebig, E.M. Rinchik, and G. Schütz. 1992. Chromosomal jumping from flanking markers defines the minimal region for alf/hsdr-1 within the albino-deletion complex. Genomics (in press).

Schmid, W., G. Müller, G. Schütz, and S. Gluecksohn-Waelsch. 1985. Deletions near the albino locus on chromosome 7 of the mouse affect the level of tyrosine aminotransferase mRNA. Proc. Natl. Acad. Sci. 82: 2866-2869.

Schöler, H.R., S. Ruppert, N. Suzuki, K. Chowdhury, and P. Gruss. 1990. New type of POU domain in germ line-specific protein Oct-4. Nature 344: 435-439.

Shemshedini, L., R. Knauthe, P. Sassone-Corsi, A. Potron, and H. Gronemeyer. 1991. Cell-specific inhibitory and stimulatory effects of Fos and Jun on transcription activation by nuclear receptors. EMBO J. 10: 3839-3849.

Stoner, E., H. Starkman, D. Wellner, V.P. Wellner, S. Sassa, A.B. Rifkind, A. Grenier, P.G. Steinherz, A. Meister, M.I. New, and L.S. Levine. 1984. Biochemical studies of a patient with hereditary hepatorenal tyrosinemia: Evidence of glutathione deficiency. Pediatr. Res. 18: 1332-1336.

Talalay, P. and H.J. Prochaska. 1987. Mechanisms of induction of NAD(P)H:quinone reductase. Chem. Scr. 27A: 61-66.

Talalay, P., M.J. De Long, and H.J. Prochaska. 1988. Identification of a common chemical signal regulating the induction of enzymes that protect against chemical carcinogenesis. Proc. Natl. Acad. Sci. 85: 8261-8265.

Tanguay, R.M., J.P. Valet, A. Lescault, J.L.Duband, C. Laberge, F. Lettre, and M. Plante. 1990. Different molecular basis for fumarylacetoacetate hydrolase deficiency in the two clinical forms of hereditary tyrosinemia (type I). Am. J. Hum. Genet. 47: 308-316.

Thaler, M.M., R.P. Erickson, and A. Pelger. 1976. Genetically determined abnormalities of microsomal enzymes in liver of mutant newborn mice. Biochem. Biophys. Res. Commun. 72: 1244-1250.

Thorndike, J., M.J. Trigg, R. Stockert, S. Gluecksohn-Waelsch, and C.F. Cori. 1973. Multiple biochemical effects of a series of X-ray induced mutations at the albino locus in the mouse. Biochem. Genet. 9: 25-39.

Tönjes, R.R., K.G. Xanthopoulos, J.E. Darnell Jr., and D. Paul. 1992. Transcriptional control in hepatocytes of normal and c14CoS albino deletion mice. EMBO J. 11: 127-133.

Trigg, M.J. and S. Gluecksohn-Waelsch. 1973. Ultrastructural basis of biochemical effects in a series of lethal alleles in the mouse. J. Cell Biol. 58: 549-563.

Weinberg, A.G., C.E. Mize, and H.G. Worthen. 1976. The occurrence of hepatoma in the chronic form of hereditary tyrosinemia. J. Pediatr. 88: 434-438.

Yang-Yen, H.-F., J.-C. Chambard, Y.-L. Sun, T. Smeal, T.J. Schmidt, J. Drouin, and M. Karin. 1990. Transcriptional interference between c-Jun and the glucocorticoid receptor: Mutual inhibition of DNA binding due to direct proteinprotein interaction. Cell 62: 1205-1215.

Yeoh, G.C.T., F.A. Bennett. and J.T. Oliver. 1979. Hepatocyte differentiation in culture: Appearance of tyrosine aminotransferase. Biochem. J. 180: 545-549. 


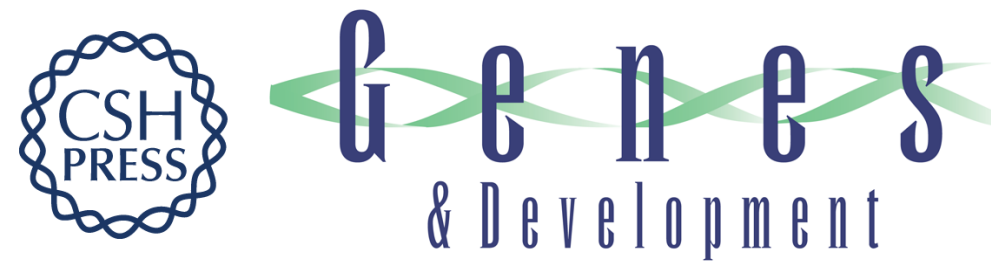

\section{Deficiency of an enzyme of tyrosine metabolism underlies altered gene expression in newborn liver of lethal albino mice.}

S Ruppert, G Kelsey, A Schedl, et al.

Genes Dev. 1992, 6:

Access the most recent version at doi:10.1101/gad.6.8.1430

References This article cites 66 articles, 23 of which can be accessed free at: http://genesdev.cshlp.org/content/6/8/1430.full.html\#ref-list-1

License

Email Alerting

Service

Receive free email alerts when new articles cite this article - sign up in the box at the top right corner of the article or click here.

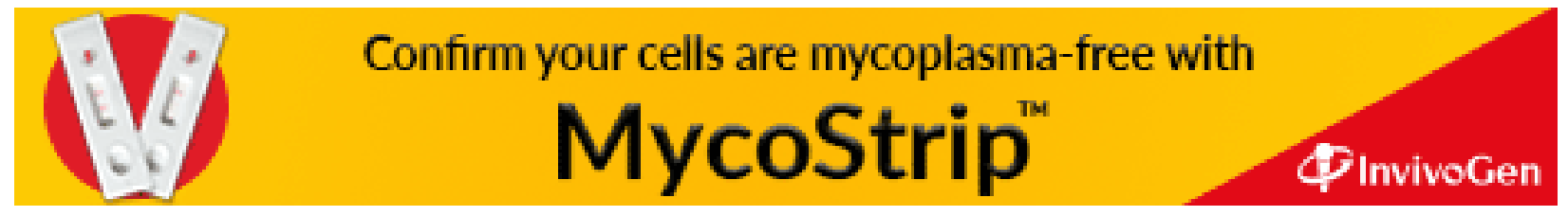

